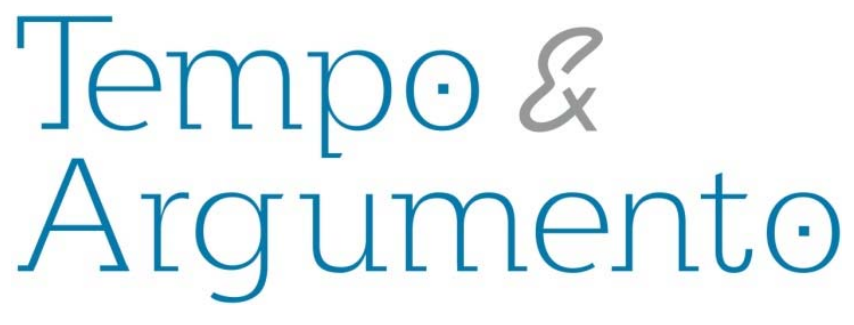

\title{
The development of the popular movement and rise of the revolutionary left in Chile (1953-1978) ${ }^{1}$
}

\begin{abstract}
The Movimiento de Izquierda Revolucionaria (MIR) of Chile, was a political-military organization, ideologically attached to Marxism-Leninism, but also inheritor in the political and symbolic level of the Cuban Revolution and Guevarism. The MIR was founded in August 1965, and has extensive and relevant political career. Nevertheless, the studies on the MIR are still scarce and multiple aspects associated with their insertion in the political history of Chile in the last third of the 2oth century, remain unknown. In this article we analyze the historical conditions in which the Chilean MIR was formed and its contribution to the process of political radicalization that took place in Chile between 1967 and 1973. Similarly, its ability to react to the repressive violence deployed by the dictatorship from 1973 and its role in organizing popular resistance are also studied.
\end{abstract}

Keywords: Movimiento de Izquierda Revolucionaria; Chile; Unidad Popular; Dictadura.

\section{Igor Goicovic Donoso}

Professor in the Ph.D. course in History at the Department of History of Universidad de Santiago de Chile (USACH) and in the Ph.D. course in the Latin American Studies of the Institute of Advanced Studies of USACH.

Chile.

igor.goicovic@usach.cl

\section{Translator}

\section{Evandro Lisboa Freire}

Translator and copy editor in English and Spanish. MA in Applied Linguistics (PUC-SP).

Specialist in Translation (UNIBERO). Brazil

elf_translation@yahoo.com.br

\section{To cite this translation:}

GOICOVIC DONOSO, Igor. The development of the popular movement and rise of the revolutionary left in Chile (1953-1978). Tempo e Argumento, Florianópolis, v. 7, n.16, p. 329 - 352. set./dez. 2015. Original title: El desarrollo del movimiento popular y el surgimiento de la izquierda revolucionaria en Chile (1953-1978)

\section{DOI: $10.5965 / 2175180307162015329$}

http://dx.doi.org/10.5965/21751803071652015329

\footnotetext{
${ }^{1}$ This paper is a part of the research project FONDECYT N ${ }^{\circ} 1130323$, Contexto histórico y dinámicas políticas de la insurgencia armada en Chile (1978-1994).
} 
O desenvolvimento do movimento popular e o surgimento da esquerda revolucionária no Chile (1953-1978)

\author{
El desarrollo del \\ movimiento popular y el \\ surgimiento de la izquierda \\ revolucionaria en Chile \\ (1953-1978)
}

\begin{abstract}
Resumo
O Movimento de Esquerda Revolucionária (MIR), do Chile, foi uma organização político-militar, ideologicamente ligado ao marxismo-leninismo, mas também herdeira no plano político e simbólico da Revolução Cubana e do Guevarismo. O MIR foi fundado em agosto de 1965, e tem uma vasta e relevante trajetória política. No entanto, os estudos sobre o MIR ainda são escassos e múltiplos aspectos associados à sua inserção na história política do Chile no último terço do século $\mathrm{XX}$, permanecem desconhecidos. Este artigo analisa as condições históricas em que o MIR chileno foi formado e sua contribuição para o processo de radicalização política que teve lugar no Chile entre 1967 e 1973. Da mesma forma, estuda-se a sua capacidade de reagir frente à violência repressiva implantada pela ditadura de 1973 e seu papel na organização da resistência popular.
\end{abstract}

Palavras-chave: Movimento de Esquerda Revolucionária; Chile; Unidade Popular; Ditadura.

\begin{abstract}
Resumen
El Movimiento de Izquierda Revolucionaria (MIR), de Chile, fue una organización político-militar, adherida ideológicamente al marxismo-leninismo, pero también heredera en el plano político y simbólico de la Revolución Cubana y del guevarismo. EI MIR fue fundado en agosto de 1965, y posee una dilatada y relevante trayectoria política. No obstante ello, los estudios sobre el MIR aún son escasos y múltiples aspectos asociados a su inserción en la historia política de Chile del último tercio del siglo $\mathrm{XX}$, permanecen desconocidos. En este artículo nos proponemos analizar las condiciones históricas en las cuales se formó el MIR chileno y su contribución al proceso de radicalización política que se vivió en Chile entre 1967 y 1973. De la misma manera, se estudia su capacidad de reacción frente a la violencia represiva desplegada por la dictadura a partir de 1973 y su rol en la organización de la resistencia popular.
\end{abstract}

Palabras clave: Movimiento de Izquierda

Revolucionaria; Chile; Unidad Popular; Dictadura.

Changes in the economic, social, and political spheres rocked the Chilean society in the mid- $20^{\text {th }}$ century. The modernization process opened in the late $19^{\text {th }}$ century had enabled to diversify the structure of the economy, adding to the traditional exploitation of mineral resources an ever-expanding industrial sector. However, the ballasts of the agricultural economy, connected by the latifundia, continued consisting in an obstacle strongly put into question by intellectuals, social movements, and political parties in a wide spectrum. Similarly, rural-urban migration deeply changed the structure, landscape, 
encouraged the radicalization of the mass movement since the mid-1950s. Thus, by 1956 , the popular field was rising and multiple small leftist organizations began to consider the need to move towards the formation of a unitary reference to represent the alternative and revolutionary proposal in Chile.

\section{Chile in the 1950s: A society in transformation}

In the early 1950 s the changes resulting from the process of economic modernization initiated in the late $19^{\text {th }}$ century were already clear in Chile. Since 1939, the Corporación de Fomento (CORFO) had created the infrastructure necessary to deepen the country's industrialization. In that sense, the CORFO engaged in organizing the red de centrales hidroeléctricas (ENDESA), which should provide the energy resources needed to operate the manufacturing units, while the foundations for constructing the Sistema Interconectado Central (SIC). Since the mid-1940s, the CORFO had also begun oil prospecting in the region of Magallanes, which gave birth to the Empresa Nacional del Petróleo (ENAP), in 1960. Moreover, the CORFO took responsibility to put the Huachipato steelmaking plant in operation, in 1950. The Huachipato steelmaking plant came to solve a large part of the steel requirements of the metal-mechanic industry (MELLER, 1998, 47$60)$.

The supports in infrastructure, equipment, financial resources, and technical advice that the State, through the CORFO, deployed in this period favored the development of the industrial sector. Particularly the light industry (food, textiles, leather, and footwear). But since the early 1950s, it is possible to see an expansion of the domestic market and a relative development of the middle classes, which led the market to get diversified, giving rise to the intermediate goods industry (white goods, automotive, electronics) and stimulating the development of the metal-mechanic industry and the construction sector. 
Meanwhile, the Gran Minería del Cobre, which since the 1920 s began to promote salt as the mainstay of the Chilean economy, contributed with significant resources to the State by way of taxation. Indeed, between 1952 and 1960, the State held, by way of taxation, $61 \%$ of the gross profits of the large U.S. companies that exploited Chilean copper (Kennecott Corporation and Anaconda Copper Company). This surplus was key for developing the State's economic policy and social policy (MELLER, 1998, 33).

Considering the above, it is possible to notice a sustained growth of educational coverage, especially at primary and secondary (industrial) education, and a diversification of university education. On the other hand, the large cities in the country, Santiago, Valparaíso, Concepción, where the manufacturing and educational opportunities were concentrated, began to convene growing numbers of rural workers.

Table 1. Chile: Population evolution in the main cities of the country (1907-1970)

\begin{tabular}{|l|c|c|c|c|c|c|c|}
\hline $\begin{array}{l}\text { Cities / } \\
\text { conurbations }\end{array}$ & 1907 & 1920 & 1930 & 1940 & 1952 & 1960 & 1970 \\
\hline Antofagasta & 32,496 & 53,531 & 53,591 & 49,106 & 62,272 & 87,860 & 114,920 \\
\hline $\begin{array}{l}\text { Valparaíso - Viña } \\
\text { del Mar }\end{array}$ & 188,709 & 217,863 & 242,693 & 275,861 & 304,110 & 368,332 & 530,677 \\
\hline Santiago & 332,721 & 507,296 & 712,533 & 952,075 & $1,350,109$ & $1,996,142$ & $2,822,025$ \\
\hline $\begin{array}{l}\text { Concepción - } \\
\text { Talcahuano }\end{array}$ & 70,891 & 86,158 & 105,183 & 121,587 & 174,881 & 231,687 & 379,793 \\
\hline Temuco & 16,037 & 28,546 & 35,748 & 42,035 & 51,497 & 72,132 & 110,513 \\
\hline Valdivia & 15,229 & 26,854 & 34,299 & 34,496 & 45,128 & 61,334 & 85,453 \\
\hline
\end{tabular}

Source: Population censuses, respective years.

As shown in Table 1, the growth of the main cities of the country, between 1907 and 1970, was sustained. ${ }^{2}$ The same can be observed regarding the intermediate cities with fewer than 50,000 inhabitants, which became the initial step for the posterior process of moving into the big cities.

\footnotetext{
${ }^{2}$ The exceptions were the cities in the regions of Tarapacá and Antofagasta, which after the crisis of the nitrate industry (1918) went through a sharp decline, and this lasted until the late 1940 .
} 
The rural-urban migration process had begun in the last third of the $19^{\text {th }}$ century, but it became sustained from the 1920 s onwards. $^{3}$ The foundations of this process have a macroeconomic nature. On the one hand, the development of the nitrate and copper industries in Tarapacá and Antofagasta stimulated to move into these provinces rural workers from the central zone and former miners of Atacama and Coquimbo, who concentrated in nitrate offices (Chacabuco, Humberstone, Jazpampa, Pontevedra, etc.), mining camps (Chuquicamata), and intermediate cities (Calama).

On the other hand, the partial modernization of the agricultural sector (mechanization, milling industry, viticulture, etc.), led to an expanded large agricultural property (latifundium), to the detriment of farmers and small producers who were expelled from their lands or saw their livelihood strategies getting more complex.

In turn, the industrialization process became increasingly dynamic in the context of the First World War and it was consolidated through the creation of the CORFO and the adoption of the import replacement strategy.

In such a scenario of economic expansion and growth in the domestic and foreign investment there was an increased capital accumulation and the domestic market was strengthened. In line with this, the State expanded its size and diversified its functions. Society, particularly the urban society, was becoming increasingly complex and demanded a growing workforce contingent for manufacturing and services.

However, the country's cities were not prepared for mass migration. Deficits in urban infrastructure and equipment, as well as inadequacies in the public housing policy, made it very difficult to settle immigrants and complicated their livelihood strategies. In urban peripheries, poverty took hold and along with it a new social player emerged: the settler. This social subject, who became a collective player, began engaging in a series of illegal land occupations (possessions), which expanded the political action field of the popular parties (GARCÉS, 2002).

\footnotetext{
3 In the beginning of $20^{\text {th }}$ century (1907), the urban population in Chile accounted for $43 \%$ of the total population. In the end of the century (1992), the percentage of urban population reached $83 \%$ of the total. See censuses, respective years. The theme has been particularly addressed by sociology and demography. History has not significantly contributed to the analysis of the phenomenon. See, in this regard, Conning (1965), Zemelman (1971), and Coeymans (1982).
} 
In this context, experiences accumulated by the popular movement during the 1938-1948 cycle, identified with the validity of the Popular Front, were generating new political lessons that revalidated the need for a class-based and revolutionary project. This process was launched in the early 1950 s and its main protagonists were individuals employed by the public (Asociación Nacional de Empleados Fiscales, ANEF, 1943) and private sectors (Confederación de Empleados Particulares de Chile, CEPCH, 1948), teachers (Federación de Educadores de Chile, FEDECH, 1944), students gathered around the Federación de Estudiantes de la Universidad de Chile (FECH), and workers from the breakaway Confederación de Trabajadores de Chile ( $\mathrm{CTCH})$. Indeed, after a series of partial mobilizations around wage demands and rejection to the anti-inflationary policy of the governments at that time, progress was made towards the formation of a Comisión Nacional de Unidad Sindical, which prepared the political and organizational conditions that allowed founding the Central Única de Trabajadores (CUT), in February 1953.

The CUT clearly defined the need to abolish the capitalist regime to move towards a classless society, it claimed the class struggle as a political action method and declared itself as a class-based, independent agency (GARCÉS and MILOS, 1988, 100-103; BARRÍA, 1971, 37-84 and BLEST, 1957, 198-211). Under the leadership of the ANEF'S director, Clotario Blest Riffo, the CUT played a key role in the revival process of the mass movement and in the development of social struggle. An expression of this was a growing tendency towards unionization of the working class, which in the late $1960 \mathrm{~s}$ reached almost one million unionized workers. Likewise, we can see sustained development of politicization within the set of workers, a politicization process that clearly linked them to leftist organizations. Finally, we can see, also, a systematic use of general strikes and the suspension of working activities, both to ask for improved labor conditions and to denounce any abusiveness, abuse, or repressive attitude, both by employers and the State (GARCÉS and MILOS, 1988, 104-115).

This process of ideological and political rearmament of the working class deeply impacted the Partido Socialista de Chile (PS). Indeed, the PS, after the internal crisis that led to fracture of the organization into two references (the Partido Socialista de Chile and the Partido Socialista Popular), produced in the heat of critical and self-critical debates 
about the experience of the front-populist class collaboration, began a sustained process of internal discussion that matured in the proposal of "Frente de Trabajadores." According to this proposal, adopted in 1955, the PS should turn into "a strong popular organization with a revolutionary nature, which serves as a struggle instrument for taking power first, and then creating the revolutionary State" (JOBET, 1971, 20). In line with this definition, the PS should gather all forces, political and social, willing to bring the capitalist system to an end. This new approach closed the door to a whole new experience of class collaboration and favored the creation of the Frente de Acción Popular (FRAP, 1956). To constitute FRAP, the PS and the Partido Comunista (PC) concurred; and the group had strict support from the CUT.

Later (1957, 1959, 1961, and 1964), the PS reaffirmed this political strategy and, by virtue of it, the FRAP presented a program of revolutionary transformations (nationalization of primary resources, banking, and large industrial complexes, agrarian reform, and independent foreign policy), and a candidacy of its own (Salvador Allende), for the presidential elections in 1958 and 1964. After the overwhelming electoral defeat of the left-wingers in the 1964 presidential election, and strongly stressed by its leftist members, the PS dismissed the electoral process (Congreso General Ordinario de 1965), as a method for the conquest of power. Despite the above, it was also indicated that the electoral mechanisms continued to provide utility as tools of mass mobilization.

This attitude was subsequently ratified at the ordinary XXII Congreso General of the PS, held in the city of Chillán, between 24 and 26 November 1967. At that time, the Chilean socialists approved a political vote establishing in its central aspects:

The Partido Socialista, as a Marxist-Leninist organization, proposes taking power as a strategic objective this generation has to achieve, in order to establish a revolutionary State to free Chile from dependency and the economic and cultural backward and start building socialism.

Revolutionary violence is inevitable and legitimate. It is necessarily derived from the repressive and armed nature of the class-based State. It is the only way leading to take political and economic power and its subsequent defense and strengthening. Only by destroying the bureaucratic and military apparatus of the bourgeois State it is possible to consolidate the socialist revolution. 
The peaceful and legal struggle types (...) do not lead to power by themselves. The Partido Socialista sees them as limited action instruments, incorporated in the political process that leads us to armed struggle.

Consequentially, alliances established by the party are justified only insofar as they contribute to achieve strategic objectives already specified (JOBET, 1971, 130).

The theme of armed struggle has become the backbone of political proposals in the revolutionary field. In this regard, undoubtedly, the Cuban Revolution, and especially Guevarism, became the theoretical and political pillars of the new designs adopted (GARCÍA, 2012 and GASPAR, 1997).

By 1965, the radicalization process experienced by the popular movement had many inclinations. It was manifested through the rise of workers' struggles, the emergence of new social players (settlers), and accelerated action by the peasantry. It had also to do with the definition of an inherent way of the Chilean left-wingers, into which the PS was revealed as the most revolutionary organization. The theoretical, political, and moral influence of the Cuban Revolution also became increasingly apparent. Finally, it referred to the existence of a number of organizations and groups aspiring to change the political landscape through the creation of a revolutionary organization to head the mass movement, in the struggle for building socialism (PALIERAKI, 2014, 8-55).

\section{The foundation of the MIR and the emergence of the revolutionary left in Chile (1965-1967)}

Despite the significant advances experienced since the early 1950 s by the classbased inclinations within the Chilean left, this does not necessarily entailed a readjustment of its tactical guidelines. In contrast, the electoral political scene remained as the space prioritized by socialists and communists. However, discussions on the issue of the conquest of power led, since the late 1950s, to a series of splits and expulsions of members both in the PC and in the PS.

In this context, small revolutionary organizations existing in Chile since the late 1930 s and split or expelled members from traditional parties found in the Cuban 
Revolution a theoretical reference and a point of support and convergence for their political struggle. Thus, the Comité de Solidaridad con la Revolución Cubana, created by Clotario Blest, in 1961, allowed the concurrence of Trotskyist, Maoist, revolutionary Christian, and Castrist individuals. In the heat of these unitary experiences and political debates emerging within, these organizations began a slow and complex process of political unity. To do this, there was concurrence of the Movimiento 3 de Noviembre, founded in 1961 by Clotario Blest; the Partido Obrero Revolucionario (1937), with a Trotskyist inclination; the anarchosyndicalists led by Ernesto Miranda, members of the Movimiento Libertario 7 de Julio (1957); and the old Communist militants led by Luis Reinoso, expelled from the Communist Party in 1949, who in the early 1960 s were members of the Movimiento de Resistencia Antiimperialista. The backbone of this unitary process was the Vanguardia Revolucionaria Marxista (1963), mainly consisting of former members of the Partido and the Juventud Socialista, which aiming at 1964 had become the main Castrist-Guevarist reference in Chile (PALIERAKI, 2014, 10-95; SALINAS, 2013, 215278; and VALDES, 2006, 35-55).

In 1964, a political conjuncture of great relevance, such as the electoral defeat of the left-wingers in the hands of the Democracia Cristiana and its candidate for the presidency of the Republic, Eduardo Frei Montalva, generated a new and deeper debate within the popular field. The electoral strategies proved, once again, its shortcomings and weaknesses and opened a new pathway to take revolutionary positions. The waters between the traditional left reformism and revolutionary alternatives are definitely separated. The new gap allowed the sectors gathered around the revolutionary pole went on to form the vanguard of the Chilean revolution. That milestone took place on August 15, 1965, through the founding of the Movimiento de Izquierda Revolucionaria (MIR) (cf. PALIERAKI, 2014, 83-138; SANDOVAL, 1990, 5-26; and BENAVENTE, 1986, 121155).

In its Declaración de Principios, drafted in September that year, the MIR uttered the theoretical and political foundations that guided its actions. The MIR was visualized as the Marxist-Leninist vanguard of the labor class and the oppressed classes in Chile, while it was conceived as the historical heir of the Chilean revolutionary traditions. From this perspective, the purpose of the MIR was to overthrow the capitalist system and replace it 
with a government of workers and peasants, led by organizations of the proletarian power, setting the task to build socialism and a gradual extinction of the State, until getting a society without classes (MIR, 1965).

The MIR recognized the historical existence of class struggle and, accordingly, took the uncompromising struggle against exploiters, rejecting any attempt to soften this struggle. It is further argued that the $20^{\text {th }}$ century was the stage of definitive agony of the capitalist system. For the MIR, in that century, the revolutionary struggle had taken a global nature, while the triumph of revolution in many countries of late capitalism (China, Algeria, North Vietnam, among others) showed that all nations had conditions enough to make the socialist revolution.

For the MIR, the Chilean bourgeoisie had demonstrated its inability to solve the bourgeois-democratic tasks: national liberation, agrarian reform, liquidation of semifeudal remnants, etc. This fact unveiled the lack of an illusory progressive bourgeoisie and, therefore, the theory of revolution by stages and the class collaboration politics assumed by the Chilean traditional left since the late 1930 s was rejected.

Later, the MIR denounced the political tactics used by the traditional left, particularly the struggle to reform the capitalist system, electioneering, abandoning direct action, peaceful and parliamentary pathway to socialism, etc. According to the MIR, these guidelines confused, defrauded, and disarmed the proletariat. The MIR proposed the armed popular insurrection as the only way to overthrow the capitalist system. Indeed, one of the most important theoretical and strategic contributions by the MIR to revolutionary thought in Chile was the introduction of armed struggle forms as a strategy to face the State and the ruling classes (LOZOYA, 2013, 173-197; CERDA and TORRES, 1999, 22 and VIDAL, 1999).

\section{The second foundation and the cycle of rise of the revolutionary struggle in Chile (1967-1973)}

At the Tercer Congreso del MIR, held in Santiago city in December 1967, the Castrist-Guevarist sector, led by Miguel Enríquez, Bautista Van Schowen, Luciano Cruz, and Andrés Pascal, won the majority of the Comité Central (CC) -10 out of the 15 
represented by former Trotskyist militants and young members around focalism were marginalized in the organization. From this moment, a new organizational model was designed. The Grupos Político-Militares (GPMs), which were intermediate organizational structures that articulated mass, operational, and technical and infrastructure (support networks) bases, were formed. From this moment, the recruiting policy became more rigorous, selection criteria were applied from the perspective of building a party with boards and, at the same time, there emerged a policy of armed actions (mainly financial recoveries), which pointed out to set the special units in flames and develop the structures of assurance (MIR, 03/1970). Through such operations, the MIR aimed to establish a link between the material conditions of workers, the deployment of armed actions to recover financial resources and reinvest them in strengthening the party structure. About one of these transactions, the organization stated:

1. The Movimiento de Izquierda Revolucionaria (MIR) informs the people that its "Comando Rigoberto Zamora" expropriated the Banco Nacional del Trabajo. The case is solved. The inefficient members of the "Escuadrón de la Muerte" do not need to torture or flagellate anyone.

2. This bank belongs to the economic clan Hirmas-Cattan-Said. This clan controls and influences, among others, the following companies: Madeco, Textil Hirmas, Algodones Hirmas, CAP, Licores Mitjans, Vestex, Manufacturas Royle, Compañía Carbonífera Colico Sur, Compac, Cobre Cerrillos, Compañía Industrial de Construcciones, etc., and many more.

The money belongs to workers from these industries, to employees from the companies, to miners from these mines, and not the thieves who had stolen from workers.

The MIR will return to all workers and peasants in the country this money, investing it in weapons and organizing the armed apparatus needed to return for all workers what all Chilean patrons have stolen from them, that is, to constitute a government for workers and farmers in order to build socialism in Chile (MIR, 02/1970).

In terms of the mass, increased class struggle within the period and the 1970 electoral conjuncture were used to penetrate the most radical sectors of the popular movement. At this point, the MIR claimed that the electoral triumph of the Unidad 
Popular (UP), in September 1970, and Salvador Allende's arrival to government, in November the same year, constituted an "excellent starting point to the direct struggle for workers to conquer power" (MIR, 09/1970). ${ }^{4}$ Consistent with these definitions, the MIR interconnected a line of intermediate fronts: Frente de Trabajadores Revolucionarios (FTR); Movimiento Universitario de Izquierda (MUI); Frente de Estudiantes Revolucionarios (FER); Movimiento Campesino Revolucionario (MCR); and the Movimiento de Pobladores Revolucionarios (MPR), intended to systematize popular demands and lead their struggles (MIR, 03/1970 and NARANJO, 1999, 14). At this level, there was a qualitative growth in the student, population, and Mapuche peasant sectors.

In parallel, political relations with some organizations and leaders of the government collation, especially with groups and directors of the PS, were strengthened. Indeed, after the defeat of the so-called 1972 "paro patronal de octubre," joint work experiences at the grassroots level, between members of the MIR and the PS, were multiplied, especially in the so-called "cordones industriales" in Santiago, Valparaíso, and Concepción (CASTILLO, 2010, 99-121 and GAUDICHAUD, 2004). This joint work was also put into practice during peasant protests in southern Chile (Temuco and Panguipulli), within the movement of settlers and in the Asamblea Popular de Concepción (July 1972) (CARCAMO, 2015, 131-155; COFRÉ, 2007, 205-238; and MONSALVEZ, 2006, 37-58; CORREA, MOLINA and YAÑEZ, 2005, 136-214). It is no wonder, therefore, that in the heat of political struggle within this period the MIR decided to support the PS parliamentary candidates in the elections of March 1973. On the contents of this support, MIR expressed them to the Socialists, in a letter in January 1973:

The MIR, behind the key objective of the period, the conquest of power, has fought and will keep driving the struggle for positions, the program and tactics developed before, today mainly expressed by the social partnership nature that we propose and the momentum of development and strengthening of a popular power.

\footnotetext{
${ }^{4}$ On the experience of the Unidad Popular (1970-1973), there are multiple records, both scientific and political and testimonial. In the compilations by Julio Pinto (2005) and Cristina Moyano (2013), it is possible to notice multiple approaches to the theme from a strictly historiographical perspective. The problem of the ways to conquer power in Marini (1976, 13-52).
} 
Given that, considering our approach concerning the nature and importance that these elections in March will take, above the existing discrepancies, based on the unfolding of some tactical agreements, and taking into account the existence of agreements concerning some primary programmatic aspects, aspiring that in the course of social and political struggle itself, they will accrue, we propose to face this electoral struggle together (MIR, 01 / 1973).

In the end of this stage, the MIR had managed to enlarge its organizational structure, on the other hand, it did deploy the primary tasks in its strategic definitions (a party with boards and armed actions) and, finally, it was consolidated as an organization at the national level, with a growing influence among the most active sectors of the mass movement.

The MIR strategy recognized the existence in Latin America, and therefore also in Chile, of a power bloc consisting of the American imperialism and the Creole ruling classes, closely linked by their economic, political, and military interests. According to the MIR, contradictions involving the two members of the power bloc were not antagonistic, they only had to do with the forms and quota amounts corresponding to them in the spoils of exploitation. However, beyond these contradictions prevailed the common interest in maintaining the domination and exploitation system on which power and wealth were based. This frame of reference led the MIR's program to be defined as antiimperialist, anti-capitalist, and socialist. According to the MIR, the ruling bloc's composition and the magnitude of its interests has made a strategy of gradual occupation of spaces within the bourgeois institutions unfeasible and, through this, advancing towards socialism, as advocated by the conglomerate of parties joined in the UP. This perception, different from the nature taken by the class struggle in Chile, led to the most acidic and violent clashes between the MIR and the UP within the period 19701973 (HERNÁNDEZ, 1999, 29-30).

The MIR, aware of the inevitability of armed conflict, proposed the construction of a Fuerza Social Revolucionaria (FSR), which was able to create a new political situation and, through this, it constructed a new legality, as the only way to solve the issue of 
CANCINO, 1988, 118-144 and GRAMEGNA and ROJAS, 1973, 125-149).

At this level, the power crisis should be tackled, necessarily, through armed confrontation, which was conceived, in the early 1970s, as a "Guerra Revolucionaria Irregular y Prolongada." From this perspective, the construction line of the FSR aimed at taking over leadership of the mass movement, and to do this it was crucial to get into the social fronts and encourage disruptive struggle forms; build parallel institutions, where the UP government and its policies should contribute to radicalize the process; develop a military force of its own, on the basis of specialized organic nuclei, armed mass, and penetration into the State's military apparatus; and radicalize revolutionary positions within parties and UP militants (MIR, 05/1973).

By 1973 , the MIR, as a result of its analysis of the national political situation and the evaluation of its insertion and leading degrees in and on the mass movement, concluded that there were only two ways for developing the class struggle in Chile: reformist capitulation to pressure by the bourgeoisie (return of occupied factories and call for a plebiscite to tackle political conflict) or revolutionary counteroffensive. If the latter triggered the Coup d'État, people believed to have the force needed to crush it. In a document from May 1973, the MIR proposed:

The crucial political task posed today, to the working class and the people, is moving towards a position essentially offensive against employers' onset of development. It means accumulating the mass force needed to prevent or win the civil war, if the employers and reactionary sectors decide to unleash it; in order to prevent reformist capitulation to the danger of civil war, and to win decisive positions in the struggle to conquer power for the working class and its allies, imposing a true Workers' Government .

\footnotetext{
${ }^{5}$ Within the period 1970-1973, clashes between MIR militants and UP supporters, especially from the PCCh, were recurrent. Similarly, the UP government took, occasionally, repressive actions against social sectors related to the MIR. The most dramatic episode took place in the camp of settlers in Lo Hermida, on August 5, 1972. At that time, the police violently raided this working-class neighborhood and shot dead a worker, and four more were seriously injured (MIR, 08/1972, 15-64).
} 
This process of accumulation of forces seeks the establishment of a revolutionary social bloc, where the working class socially drives poor people in the city, the countryside, and the petite bourgeoisie, and recognizes its leadership as a revolutionary and political alliance where the revolutionaries and radical sectors of the left are predominant (MIR, 05/1973).

Despite the above, the response by the mass movement and the MIR to the Coup d'État on September 11, 1973, was not expecting. The mass movement, baffled, beaten, and fragmented, remained most of the time in a passive position, frightened, and it did not confer resistance; while the leading sectors in the industrial neighborhoods, in towns, and in some rural areas, which took their battle fronts waiting for orders and weapons, were subsequently evicted and violently repressed (VIDAURRAZAGA, 2013, 121-192; GARCÍA, 1996, 159-218; and BLASCO and SIERPE, 2015, 107-128). In any case, the immediate balance made by the MIR diagnosed that the strategy which had failed in Chile was reformist, and not a revolutionary strategy, the latter had been exposed to the recess and reverse experienced by the popular struggle and it seemed to be politically and morally legitimate, since it was proposed as the only alternative to regain leadership over the revolutionary process (MIR, 12/1973).

\section{The organization of popular resistance in the context of the struggle for survival (1973-1978)}

In December 1973, the MIR established that the military Coup d'État had closed the pre-revolutionary period and given way to a counterrevolutionary period. The latter was characterized by the attempt of the ruling class to restore the domination system, tackling its internal crisis and crushing the mass movement. According to the MIR, the State's backbone (the Armed Forces), standing above the ruling class factions, had solved by force the State's political crisis and it was preparing to solve the drag crisis of the capitalist domination system in Chile (MIR, 12/1973).

In this new period, broader aspects of the original MIR program did not undergo major changes. The need for proletarian revolution in Chile was emphasized, which 
the working class in alliance with poor people from the countryside and the city and the lower layers of the petite bourgeoisie.

The strategic line, adapting to the new period, put more emphasis on the politicalmilitary component. The revolutionary war, particularly, should achieve a continental nature, by constituting the Junta Coordinadora Revolucionaria (JCR), which gathered the MIR from Chilean, the MLN-Tupamaros from Uruguay, the PRT-ERP from Argentina, and the ELN from Bolivia (MARCHESI, 2009, 41-72). Regarding this point, the member of the Comisión Política del MIR, Nelson Gutiérrez, stated in 1976:

$[\ldots]$ the Latin American revolution must solve the three crucial problems of every victorious revolution; the problem of constructing the social force of the revolution, i.e. the alliance of the working class, the peasantry, poor people from the city and countryside, and the radicalized petite bourgeoisie; and the great problem of military power of the proletarian revolution [...]. The victory of the proletarian revolution in Latin America and in Chile will be impossible if we do not build military power of the revolution, if we do not develop military capacity of the revolutionary party of the proletariat, if we do not develop military capacity of the mass, and do not incorporate the mass in armed struggle, if we do not urge the guerrilla struggle in the city and in the countryside $[\ldots](\mathrm{MIR}, 08 / 1976,10)$.

In order to develop this line of strategic intervention, it was a must to address a number of preliminary objectives: strengthening and invigorating the party, rebuilding the revolutionary social force, and form the Ejército Revolucionario del Pueblo (ERP) and, resorting to it, overthrow the dictatorship and conquer power. The most visible experience of this new strategic orientation of the MIR was forming and developing the Milicias de la Resistencia Popular (MRP), which played a significant role throughout the period of struggle against Dictatorship (ENRÍQUEZ, 05/1975). 
Under current conditions, at the mass level, there is no point in a political front [of the resistance] that is not grounded in a broad mass movement, which goes beyond political parties.

It seems crucial to form "below" a broad movement, which opens a channel for incorporating into the base the growing number of individuals from the sectors of the population, which, not belonging to political parties from the front, are and will increasingly turn contained dissatisfaction and anger against the dictatorship and its policy into readiness to join the fight $[\ldots]$.

To do this, we propose the constitution of the Movimiento de Resistencia Popular, to which all sections of the people that support its platform can be incorporated [...], either they are front parties' activists or not; and in the base, in every factory, farm, population, high school, college, public office, etc., they took the form of the Comite de Resistencia Popular (structuring according to their communal and provincial development, and at the national level) (MIR, 02/1974).

The projection of this strategic line was interrupted by the violent repressive actions aimed against the MIR by the State security apparatuses, especially the Servicio de Inteligencia de la Fuerza Aérea (SIFA) and the Dirección de Inteligencia Nacional (DINA) (HINER, 2009, 50-74; SOTO et al, 2008, 75-96; and VALDIVIA, 2003, 182-190). Between 1974 and 1975, thousands of militants and sympathizers of the MIR were arrested, tortured, and many of them were killed and their bodies just disappeared. Virtually the whole Comisión Política and a large part of the Comité Central del MIR were killed, also the party's Secretario General, Miguel Enríquez Espinoza, killed in combat on October 5, 1974 (PÉREZ, 2004, 355-382 and SATER, 1986, 31-45). Regarding Miguel Enríquez death, the partisan press pointed out in late 1974:

The death of our comrade Secretario General, Miguel Enríquez, has been a blow and an irretrievable loss for our party, to the left, the resistance, the Chilean revolution, and all revolutionary individuals.

We had to pay a huge tribute to the Resistance cause and the revolutionary struggle of the proletariat. The revolutionary struggle demands inescapable sacrifice from leadership. Our party, the proletariat and the Chilean people will know how to pay homage to Miguel Enriquez death in the struggle, a role model as leader and fighter, who entered history as a hero of the Chilean and Latin American proletarian revolution (MIR, 12/1974, 2). 
These repressive blows resulted in party's dismantling, and this obliged the surviving boards to readjust the organizational structure and redefine the tactical guidelines. ${ }^{6}$

The core of the surviving boards, which remained within the country, gathered in the Base Madre Miguel Enríquez, organizational agency consisting of no more than 50 militants who took the task of rebuilding the partisan instrument under the difficult conditions imposed by the repressive siege (AGUILÓ, 2010). This reduced core of the MIR tried to solve the organization problem by strengthening a tightly compartmentalized military apparatus. A fighting force that focused its strategic choice on triggering and developing the policy of Resistencia Popular. This way, the internal military structures of the party were strengthened (Estructura de Fuerza Central) and the Milicias de la Resistencia Popular gained momentum, around the most radicalized and active sectors of the mass movement: unemployed groups, organizations related to the defense of human rights, settlers, Mapuche peasants, and students (MIR, 11/1990).

The culmination of this process for organizational restructuring and reconnection of links to the mass movement was provided by the Plan 78 (better known as "Operación Retorno"), a tactical initiative aimed at strengthening the party's military structure through return to the country of political and military boards from exile; mainly from Cuba. Through this amount of people, it was intended to put into practice offensive armed actions, carrying out armed propaganda actions and striking strategic military objectives of the dictatorship (PASCAL, 1981).

Since 1978, and through the momentum that the MIR provided for developing the Milicias de la Resistencia Popular, we can observe a slow but steady process of revival of the popular mass movement (MIR, 1988, 49-64). This was expressed in rallies and mass action during the celebrations of May 1 and September 4 and 11, as well as the first workers' strikes in 1980. They are also an expression of this process of resuscitation of

\footnotetext{
${ }^{6}$ The collection of historical documents of the MIR, conducted by Miriam Ortega and Cecilia Radrigán (1998), states that 448 activists of the organization were killed, just disappeared, or died in armed clashes between September 1973 and March 1990. A detailed review of the Report by the Comisión Nacional de Verdad y Reconciliación (1991) provided the figure of 465 MIR members who were killed.
} 
college students' demonstrations against the Higher Education legislation signed by the dictatorship in 1981 and the land seizures carried out by settlers in southern Santiago city between 1980 and 1982 . To this must be added the protests by family members and colleagues of the victims of dictatorship, which had started in 1974 and acquired particular force since the 1977 hunger strike.

Thus, when massive popular protests against the dictatorship emerged, in May 1983, the mass movement had already accumulated a significant struggle experience under clandestine conditions and along with social and political organizations, such as the MIR, deeply rooted in the popular field (SILVA, 2011, 21-51).

\section{References}

AGUILÓ, Hernán. Entrevista com Hermán Aguiló. Local, 10 de abril de 2010. Entrevistadores: Eduardo Arancibia y Miguel ramos.

AMORÓS, Mario. Miguel Enríquez:un nombre en las estrellas. Biografía de un revolucionario. Santiago de Chile: Ediciones B, 2014.

BARRÍA, Jorge. Historia de la CUT. Santiago de Chile: Prensa Latinoamericana, 1971.

BENAVENTE, Andrés. Movimiento de Izquierda Revolucionaria: trayectoria y presente. Revista Política, Santiago de Chile: Universidad de Chile, n. 12, p.121-155, 1987.

BLASCO, Anna y SIERPE, Valdimir. Militantismo y resistencia socialista entre 1973 y 1975 , Revista de Historia Social y de las Mentalidades, Santiago de Chile: Departamento de Historia de la Universidad de Santiago de Chile v. 19, n. 1, p. 107-128, 2015.

BLEST, Clotario. La CUT y los partidos políticos (1957), In: SALINAS, Maximiliano (Ed.). Clotario Blest. Santiago de Chile: Arzobispado de Santiago, Vicaría de la Pastoral Obrera, 1980.

CANCINO, Hugo. La problemática del poder popular en el proceso de la vía chilena al socialismo: 1970-1973. Aarhus: Aarhus University Press, 1988.

CÁRCAMO, Ovidio. Juventud rebelde, campesinado indígena y la instalación del discurso 
de clases en los campos de Cautín. Movimiento Campesino revolucionario (Chile, 19671973), Revista de Historia Social y de las Mentalidades, Santiago de Chile : Departamento de Historia de la Universidad de Santiago de Chile, v. 19, n. 1, p.131-155, 2015. ,

CASTILLO, Sandra. Sociabilidad y organización política popular: Cordón industrial CerrillosMaipú (Santiago, 1972). Cuadernos de Historia, Santiago de Chile: Universidad de Chile, n. 32, p. 99-121, 2010.

CERDA, Luis y TORRES, Ignacio. La visión estratégica del Che y Miguel sobre la revolución latinoamericana, In: NARANJO, Pedro (Coord.). Miguel Enríquez:páginas de historia y lucha. Estocolmo: Centro de Estudios Miguel Enríquez (CEME), 1999.

COEYMANS, Juan Eduardo. Determinantes de la migración rural urbana en Chile según origen y destino. Santiago de Chile: Pontificia Universidad Católica de Chile, 1982.

COFRÉ, Borís. Campamento Nueva La Habana: El MIR y el movimiento de pobladores, 1970-1973. Concepción: Escaparate Ediciones, 2007.

CONNING, Arthur M. Estimación de la migración interna neta, clasificada por edad y por sexo, en las provincias y regiones en Chile durante los años 1930-1940, 1940-1952 y 19521960. Santiago de Chile: CELADE, 1965.

CORREA, Martín, MOLINA, Raúl y YAÑEZ, Nancy. La reforma agraria y las tierras mapuches: Chile, 1962-1975. Santiago de Chile: LOM Ediciones, 2005.

ENRIQUEZ, Edgardo et al. Discurso pronunciado por el miembro de la comisión política y responsable exterior del MIR, en el acto organizado por el comité de apoyo a la lucha revolucionaria del pueblo chileno en el salón de actos de la Mutualité de París. París, 5 de febrero de 1975, MIR. Madrid, 1976.

GARCÉS, Mario y MILOS, Pedro. FOCH, CTCH, CUT: las centrales unitarias en la historia del sindicalismo chileno. Santiago de Chile: ECO, 1988.

GARCES, Mario. Tomando su sitio. El movimiento de pobladores de Santiago, 1957-1970. Santiago de Chile: LOM Ediciones, 2002.

GARCÍA, Cecilio. Revolución Cubana: historia, conflictos y desafíos. Concepción: Editorial Escaparate, 2012.

GARCÍA, Francisco. Historias derrotadas: opción y obstinación de la guerrilla chilena (1965-1988). Morelia: Universidad Michoacana de San Nicolás de Hidalgo, 1996.

GASPAR, Gabriel. Guerrillas en América Latina. Santiago de Chile: FLACSO, 1997. 
GAUDICHAUD, Franck. Poder popular y cordones industriales:estimonios sobre el movimiento popular urbano, 1970-1973. Santiago de Chile: LOM Ediciones, 2004.

GRAMEGNA, Marco y ROJAS, Gloria. La izquierda revolucionaria en la lucha política e ideológica actual.Marxismo y Revolución, Santiago de Chile, n.1, p. 125-149, 2015. HERNÁNDEZ, Martín. Carácter y programa de la revolución proletaria en la concepción de Miguel Enríquez, In NARANJO, Pedro (Coord.). Miguel Enríquez: páginas de historia y lucha. Estocolmo: Centro de Estudios Miguel Enríquez (CEME), 1999.

HINER, Hillary. Voces soterradas, violencia ignoradas: Discurso, violencia, política y género en los Informes Rettig y Valech. Latin American Research Review, Austin: Latin American Studies Association, v. 44, n. 3, p.50-74-, 2009.

JOBET, Julio Cesar. El Partido Socialista de Chile: tomo II. Santiago de Chile: Prensa Latinoamericana, 1971.

LEIVA, Sebastián. Revolución socialista y poder popular: los casos del MIR y PRT-ERP, 1970-1976. Concepción: Ediciones Escaparate, 2010.

LOZOYA, Ivette. Pensar la revolución: Pensamiento latinoamericano e intelectuales en el MIR chileno, 1965-1973. Propuesta teórica y metodológica para su estudio desde la historia intelectual y la historia de la violencia. Revista de Humanidades, Santiago de Chile: Universidad de Santiago de Chile, n. 27, p.173-197, 2013.

MARCHESI, Aldo. Geografía de la protesta armada: Nueva izquierda y latinoamericanismo en el cono sur. El ejemplo de la Junta de Coordinación Revolucionaria. Sociohistórica. La Plata: Universidad Nacional de La Plata, n. 25, p.41-72, 2009.

MARINI, Ruy. El reformismo y la contrarrevolución: estudios sobre Chile. México D.F.: Editorial ERA, 1976.

MELLER, Patricio. Un siglo de economía política chilena (1890-1990). Santiago de Chile: Editorial Andrés Bello, 1998.

MIR. Algunos antecedentes el Movimiento de Izquierda Revolucionaria. Santiago de Chile, marzo de 1970, In: RADRIGÁN, Cecilia y ORTEGA, Miriam (Eds.). Miguel Enríquez: con vista a la esperanza. Santiago de Chile: Escaparate Editores, 1998a.

MIR. Balance histórico del MIR y de su lucha revolucionaria. In: CONGRESO DEL MIR, IV, Santiago de Chile, 1988. Documento de discusión. Santiago de Chile, 1988. 
MIR. Carta del MIR al PS. Santiago de Chile, enero de 1973, In: RADRIGÁN, Cecilia y ORTEGA, Miriam (Eds.). Miguel Enríquez: con vista a la esperanza. Santiago de Chile: Escaparate Editores, 1998b.

MIR. Declaración de principios, El Rebelde, Santiago de Chile, 1 de septiembre de 1965.

MIR. Declaración pública. El MIR a los obreros, campesinos, pobladores estudiantes y soldados. Santiago de Chile, septiembre de 1970, In: Radrigán, Cecilia y Ortega Miriam (Eds.). Miguel Enríquez: Con vista a la esperanza. Santiago de Chile: Escaparate Editores, 1998c.

MIR. Declaración pública: A los obreros, campesinos, pobladores y estudiantes. Santiago de Chile, Secretariado Nacional del MIR, 23 de febrero de 1970.Punto Final, n. 99, p.5,3, 3 de marzo de 1970

MIR. Discurso del compañero Nelson Gutiérrez, miembro de la Comisión Política. La Habana: agosto de 1976.

MIR. Documento Central. Conferencia Nacional Extraordinaria. Santiago de Chile, noviembre de 1990.

MIR. Editorial. A los trabajadores y a los revolucionarios del mundo. El Rebelde, n. 102, Santiago de Chile, diciembre de 1974.

MIR. La táctica del MIR en el actual período. Santiago de Chile, Comisión Política, diciembre de 1973, In: Radrigán, Cecilia y Ortega Miriam (Eds.). Miguel Enríquez: con vista a la esperanza. Santiago de Chile: Escaparate Editores, 1998d.

MIR. Lo Hermida: la cara más fea del reformismo. Santiago de Chile: Ediciones El Rebelde, 08/1972.

MIR. Pauta del MIR para unir fuerzas dispuestas a impulsar la lucha contra la dictadura. Santiago de Chile, Comisión Política, 17 de febrero de 1974, In: Radrigán, Cecilia y Ortega Miriam (Eds.). Miguel Enríquez: con vista a la esperanza. Santiago de Chile: Escaparate Editores, 1998e.

MIR. Resoluciones del Comité Central sobre la situación política nacional. Santiago de Chile, Comité Central del MIR, mayo de 1973. In: Radrigán, Cecilia y Ortega Miriam (Eds.). Miguel Enríquez: con vista a la esperanza. Santiago de Chile: Escaparate Editores, $1998 \mathrm{f}$.

MONSALVEZ, Danny. La Asamblea del Pueblo en Concepción. La Expresión del poder popular. Revista de Historia. Concepción: Universidad de Concepción, v.16, n. 2, p.37-58, 2006. 
MOYANO, Cristina (Ed). A 40 años del golpe de Estado en Chile. Santiago de Chile: Editorial USACH, 2013.

NARANJO, Pedro. Semblanza biográfica y política de Miguel Enríquez. In NARANJO, Pedro (Coord.). Miguel Enríquez:páginas de historia y lucha. Estocolmo: Centro de Estudios Miguel Enríquez (CEME), 1999.

PALIERAKI, Eugenia. La revolución ya viene: el MIR chileno en los años sesenta. Santiago de Chile: LOM Ediciones, 2014.

PASCAL, Andrés. Neltume es un paso. El objetivo: La guerrilla permanente en los campos. Entrevista al Secretario General del MIR, Andrés Pascal Allende. Revista Punto Final (en la clandestinidad), Santiago de Chile, 1981.

PÉREZ, Cristián. Años de disparos y tortura (1973-1975: Los últimos días de Miguel Enríquez. Estudios públicos, Santiago de Chile, Centro de Estudios Públicos, n. 96, p. 355382, 2004.

PINTO, Julio (Coord.). Cuando hicimos historia: la experiencia de la Unidad Popular. Santiago de Chile: LOM Editores, 2005.

RADRIGÁN, Cecilia; Ortega Miriam (Eds.). Miguel Enríquez: con vista a la esperanza. Santiago de Chile: Escaparate Editores, 1998.

SALINAS, Sergio. El tres letras: historia y contexto del Movimiento de Izquierda Revolucionaria. Santiago de Chile: RIL Editores, 2013.

SANDOVAL, Carlos. MIR: una historia. Santiago de Chile: Sociedad Editorial Trabajadores, 1990.

SATER, William. El Movimiento de la Izquierda Revolucionaria y Chile. Revista Occidental, Tijuana: Instituto de Investigación y Documentación Latinoamericana, Año 3, n. 1, p.31$45,1986$.

SILVA, Robinson. Resistentes y clandestino:a violencia política del MIR en la dictadura profunda, 1978-1982. Concepción: Ediciones Escaparate, 2011.

SOTO, Alvaro et al. Transición a la democracia en Chile y derechos humanos: Una revisión del Informe Rettig, In: Historia del Presente, Madrid. Asociación Historiadores del Presente, v. 12, n. 2, p.75-96, 2008. 
VALDÉS, Pedro. Elementos teóricos en la formación y desarrollo del MIR durante el período 1965-1970. 2006, oof. Tesis (Liceniatura in..... ) - Universidad de Valparaiso, Doutorado em...., Valparaiso, 2006.

VALDIVIA, Veronica. Terrorism and political violence during the Pinochet years: Chile, 19731989. Radical History Review, New York: New York University. n. 85, p.182-190, 2003.

VIDAL, Hernán. Presencia del MIR: 14 claves existenciales. Santiago de Chile: Mosquito Editores, 1999.

VIDAURRAZAGA, Ignacio. Martes once: la primera resistencia. Santiago de Chile: LOM Ediciones, 2013.

VITALE, Luis. Contribución a la historia del MIR (1965-1970). Santiago de Chile: Ediciones Instituto de Investigación de Movimientos Sociales Pedro Vuskovic, 1999.

ZEMELMAN, Hugo. El migrante rural. Santiago de Chile: ICIRA, 1971.

Received on August 06, 2015. Accepted on September 20, 2015.

Universidade do Estado de Santa Catarina - UDESC

Programa de Pós-Graduação em História - PPGH

Revista Tempo e Argumento Volume 07 - Número 16 - Ano 2015 tempoeargumento@gmail.com 